\title{
Advances in the State-of-the-Art of Hammer Forged Alloy 718 Aerospace Components
}

\author{
Gangshu Shen, Dan Kahlke, Robb Denkenberger, and David Furrer \\ Ladish Co., Inc. \\ 5481 South Packard Avenue \\ Cudahy, WI 53110-8902
}

\begin{abstract}
Computer controlled hammer $(\mathrm{CCH})$ forging results in a reproducible, pre-programmed hammer blow energy and blow sequence, and a record of the actual velocity, energy and operation timing for each forged component. This new capability in hammer forging allows for sophisticated hammer forging processes executed under accurate control. At the same time, it also makes the process and microstructure modeling of hammer forging possible. In this study, hammer forging of Alloy 718 was performed run using a computer controlled hammer, and the microstructure and properties of the forged disks were evaluated. The process and microstructure modeling of the hammer forging was performed and correlated with experimental results. The results indicate that hammer forging can be run under accurate control and produce disks with high quality of microstructures and properties. This research also shows process and microstructure modeling of hammer forging is a powerful tool for the process development of high quality Alloy 718 components.
\end{abstract}




\section{Introduction}

Equipped with variety of hammers, from small to the largest in the world, Ladish operates one of the most established and diversified hammer forge shops in the world. With the development of computer controlled hammer capability, hammer forge modeling has greatly increased in sophistication and accuracy [1-4]. There were three problems that hindered hammer forging simulation in the past: (1) there was no user-friendly software available; (2) there were no high strain rate flow stress data available; and (3) there were no reliable methods for blow energy partition assignment [5]. Recently, DEFORM ${ }^{\mathrm{TM}}$ developed a very user friendly hammer module, which makes the preparation for hammer forging simulation as easy as that for hydraulic press simulation. All of the important hammer forging specific information, such as the number of blows, the blow energy assigned for each blow, manipulating workpieces after a certain number of blows and resting time between blows, etc. can be easily entered into a table. Thus, the first problem concerning user friendly software was solved. Facilities are now available that can perform isothermal flow stress tests with strain rates up to $100 / \mathrm{s}$. This has solved the second problem of flow stress data availability. Ladish has developed an in-house modeling capability to predict energy partitioning characteristics for all hammer forging processes. The methodology has been verified by numerous hammer forging trials including materials of 4340 steel, Ti-6242, Alloy 718, and Waspaloy and dies with different configurations and hammers from $160 \mathrm{~kJ}$ to $1500 \mathrm{~kJ}$ in size. This research has also shown that with the help of computer simulation of the hammer forging process and component microstructure, optimized and tightly controlled microstructures and mechanical properties are possible by means of hammer forging.

\section{Experiments}

Experimental disks were hammer forged from different materials and into different configurations to demonstrate and validate computer controlled hammer forging methods and computer process and microstructure simulations. Four sets of dies were used in this program: Experimental Disk-1 Preform Shape (ED1-P), and Experimental Disk-1 Finish Shape (ED1-F), Experimental Disk-2 Preform Shape (ED2-P), and Experimental Disk-2 Finish Shape (ED2-F). Materials that were forged included 4340 steel, Ti-6242, Alloy 718, and Waspaloy. The workpiece and die configurations are shown in Figures 1-2.

A total of 20 pieces of 4340 steel billets were forged in a step-down manner in the four pairs of dies shown in figures 3-4. A model was developed to describe the energy partitioning of hammer forging. Energy partitioning predictions were compared to those determined from the hammer step-down trials. 


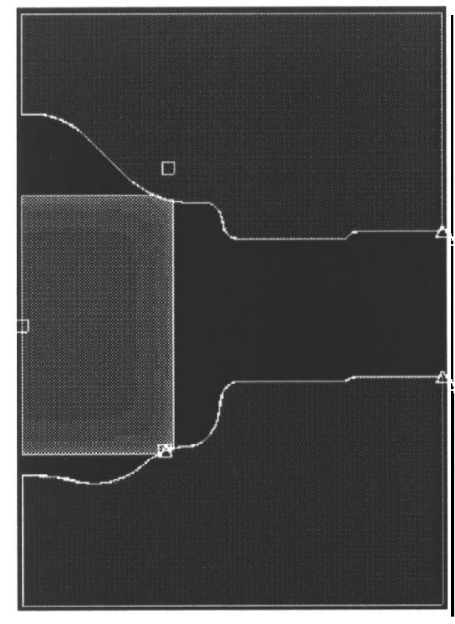

Billet

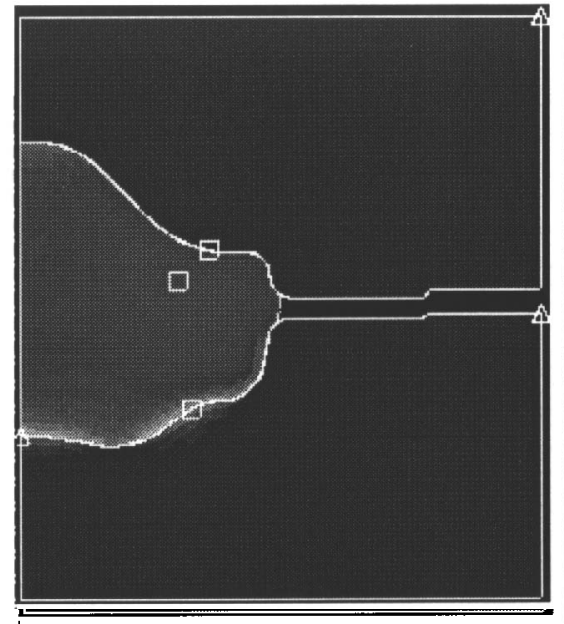

Preform

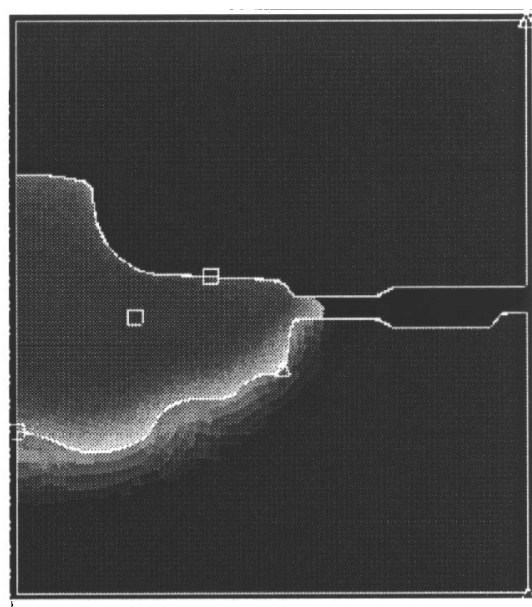

$\mathbb{C} \quad$ Forge

Fig. 1 Experimental Disk-1 Preform Shape (ED1-P) and Experimental Disk-1 Finish Shape (ED1-F) along with the initial billet and final forged material.

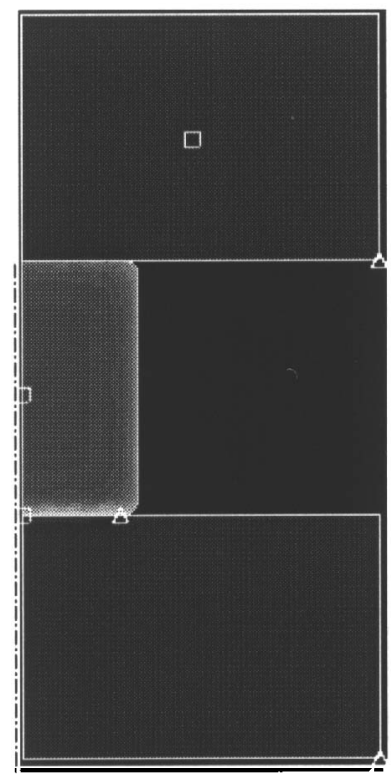

$\mathbb{C}$ Billet

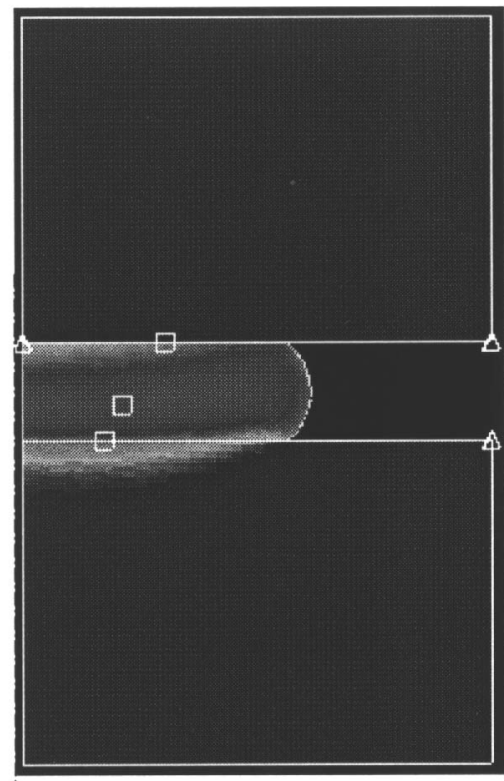

C Pancake

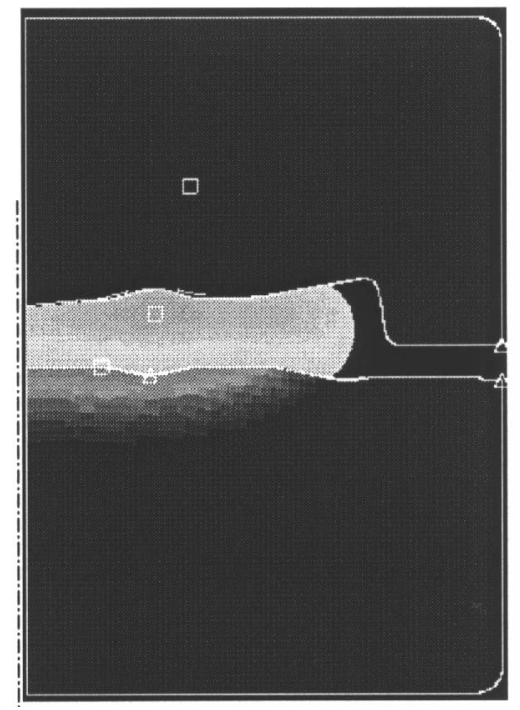

Finish

Fig. 2 Experimental Disk-2 Preform Shape (ED2-P) and Experimental Disk-2 Finish Shape (ED2-F) along with the initial billet and final forged material. 


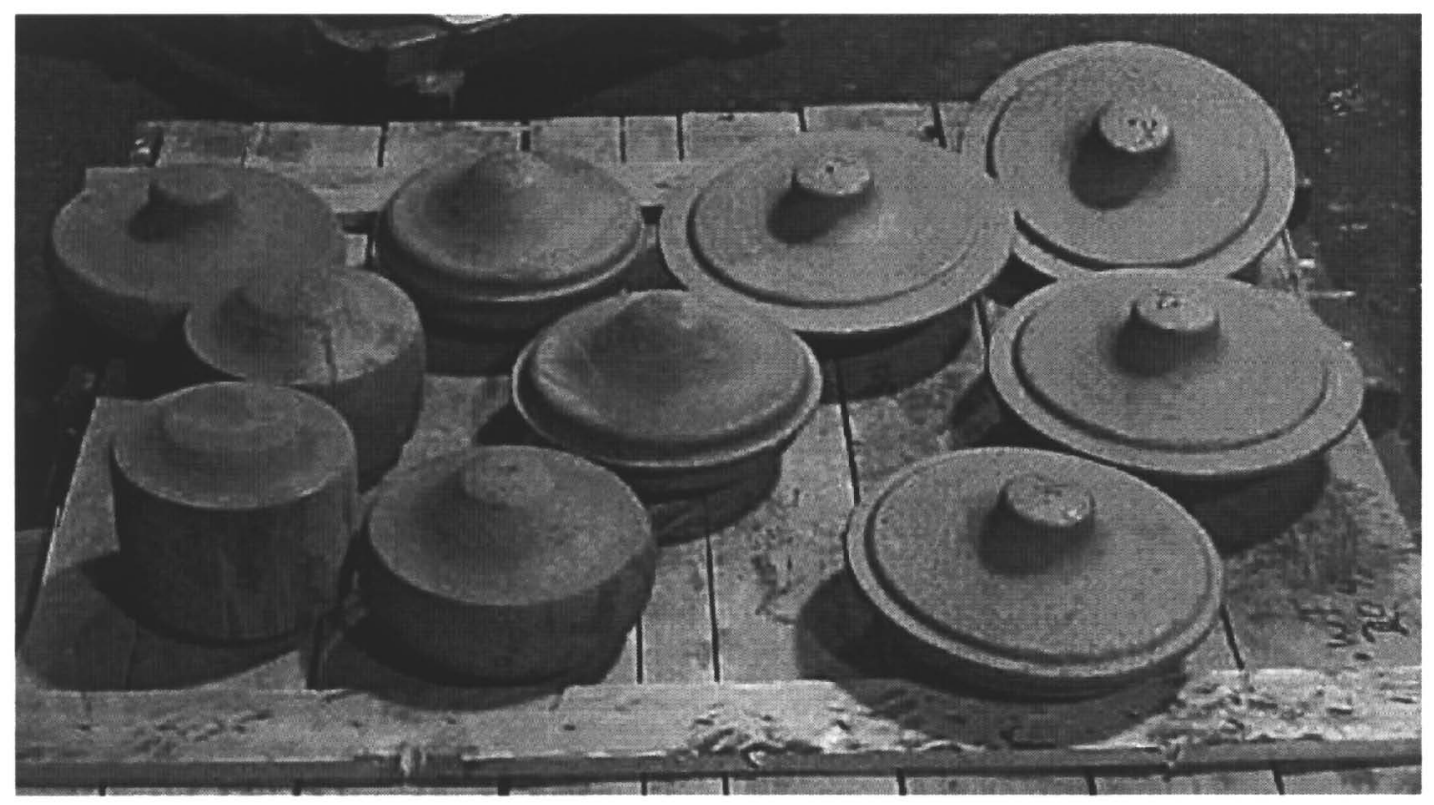

Fig. 3 Step-down forgings produced in Experimental Disk-1 Preform/Finish dies using 4340 material.

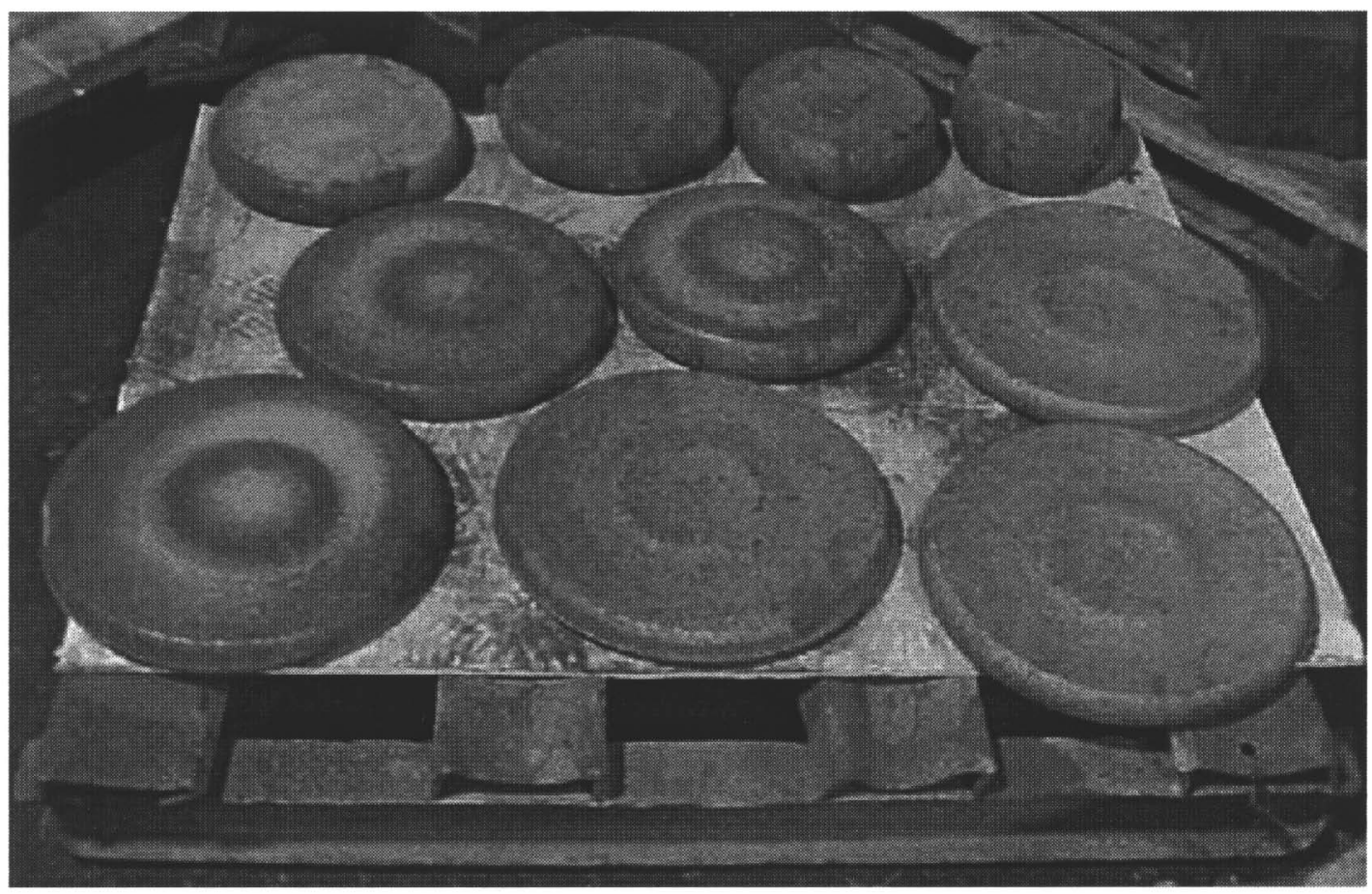

Fig. 4 Step-down forgings produced in Experimental Disk-2 Preform/Finish Shape dies using 4340 material. 


\section{Results}

\section{Hammer Forging Process Modeling}

Using the energy partitioning model developed at Ladish, the hammer forging simulations were performed for the 20 pieces of 4340 steel forgings. The values of experimentally measured and predicted geometries of the disks are shown in Tables 1-4. It is seen from the comparison that the model predictions agree very well with the measurements.

Table 1 Comparison of Measured and Predicted Dimensions for Experimental Disk-1 Preform Shape Forging Step Down

\begin{tabular}{|r|r|r|r|r|r|}
\hline S/N & $\begin{array}{r}\text { Preform } \\
\text { \#of Blows }\end{array}$ & $\begin{array}{r}\text { Radius } \\
\text { Measured }\end{array}$ & $\begin{array}{r}\text { Radius } \\
\text { Predicted }\end{array}$ & $\begin{array}{r}\text { Thickness } \\
\text { Measued }\end{array}$ & $\begin{array}{r}\text { Thicknes } \\
\text { Predicted }\end{array}$ \\
\hline & 1 & & & & \\
\hline 21 & 2 & 3.39 & 3.38 & 4.53 & 4.50 \\
\hline 22 & 3 & 3.77 & 3.76 & 3.66 & 3.61 \\
\hline 23 & 4 & 4.26 & 4.19 & 2.77 & 2.74 \\
\hline 24 & 5 & 4.58 & 4.64 & 2.50 & 2.48 \\
\hline 25 & 6 & 4.86 & 4.91 & 2.45 & 2.45 \\
\hline
\end{tabular}

Table 2 Comparison of Measured and Predicted Dimensions for Experimental Disk-1 Finish Shape Forging Step Down

\begin{tabular}{|r|r|r|r|r|r|}
\hline S/N & $\begin{array}{r}\text { Finish } \\
\text { \#of Blows }\end{array}$ & $\begin{array}{r}\text { Radius } \\
\text { Measured }\end{array}$ & $\begin{array}{r}\text { Radius } \\
\text { Predicted }\end{array}$ & $\begin{array}{r}\text { Thickness } \\
\text { Measued }\end{array}$ & $\begin{array}{r}\text { Thickness } \\
\text { Predicted }\end{array}$ \\
\hline & 1 & & & & \\
\hline 26 & 2 & 4.89 & 4.83 & 1.76 & 1.78 \\
\hline & 3 & & & & \\
\hline 27 & 4 & 5.37 & 5.49 & 1.62 & 1.62 \\
\hline & 5 & & & & \\
\hline 28 & 6 & 5.86 & 5.69 & 1.60 & 1.60 \\
\hline 29 & 7 & 6.05 & 5.78 & 1.60 & 1.59 \\
\hline & 8 & & & & \\
\hline 30 & 9 & 5.86 & 5.86 & 1.60 & 1.56 \\
\hline
\end{tabular}


Table 3 Comparison of Measured and Predicted Dimensions for Experimental Disk-2 Preform Shape Forging Step Down

\begin{tabular}{|r|r|r|r|r|r|}
\hline S/N & $\begin{array}{r}\text { Pancake } \\
\text { \#of Blows }\end{array}$ & $\begin{array}{r}\text { Radius } \\
\text { Measured }\end{array}$ & $\begin{array}{r}\text { Radius } \\
\text { Predicted }\end{array}$ & $\begin{array}{r}\text { Thickness } \\
\text { Measued }\end{array}$ & $\begin{array}{r}\text { Thickness } \\
\text { Predicted }\end{array}$ \\
\hline & 1 & & & & \\
\hline & 2 & & & & \\
\hline 31 & 3 & & & & \\
\hline & 4 & 4.23 & 4.08 & 5.00 & 5.09 \\
\hline 32 & 5 & & & & \\
\hline & 6 & 5.08 & 4.90 & 3.33 & 3.50 \\
\hline 33 & 7 & & & & \\
\hline 34 & 8 & 5.77 & 5.68 & 2.48 & 2.55 \\
\hline
\end{tabular}

Table 4 Comparison of Measured and Predicted Dimensions for Experimental Disk-2 Finish Shape Forging Step Down

\begin{tabular}{|r|r|r|r|r|r|}
\hline S/N & $\begin{array}{r}\text { Finish } \\
\text { \#of Blows }\end{array}$ & $\begin{array}{r}\text { Radius } \\
\text { Measured }\end{array}$ & $\begin{array}{r}\text { Radius } \\
\text { Predicted }\end{array}$ & $\begin{array}{r}\text { Thickness } \\
\text { Measued }\end{array}$ & $\begin{array}{r}\text { Thickness } \\
\text { Predicted }\end{array}$ \\
\hline & 1 & & & & \\
\hline 40 & 2 & 6.49 & 6.51 & 2.01 & 2.09 \\
\hline & 3 & & & & \\
\hline 36 & 4 & 7.10 & 7.09 & 1.87 & 1.94 \\
\hline 37 & 5 & & & & \\
\hline 38 & 6 & 7.54 & 7.54 & 1.75 & 1.79 \\
\hline 39 & 7 & 7.56 & 7.56 & 1.77 & 1.78 \\
\hline & 8 & 7.56 & 7.56 & 1.78 & 1.78 \\
\hline 35 & 9 & & & & \\
\hline
\end{tabular}

In addition to the twenty 4340 steel parts, computer modeling simulations were performed for Ti-6242 and Alloy 718. These models were verified thru the manufacture of six Ti-6242, and nine Alloy 718 disks in each configuration. Again, the simulations agreed very well with the experiments. These results show that hammer forging process simulation is quite robust and will allow further implementation of simulation tools for microstructure prediction of hammer forged components.

\section{Microstructure Modeling of Alloy 718 Hammer Forging}

Since the FEM simulation of hammer forging has been shown to be reliable, the entire thermal mechanical histories of a hammer forged part can be obtained for use in the microstructure modeling [6-7]. Recrystallization and grain size were predicted for Alloy 718 forgings produced in this project. The forging process for Experimental Disk-1 Shape was designed to show an intentional transition between the recrystallized and unrecrystallized zones. Figure 5 shows the comparison of the border between recrystallized and unrecrystallized zones obtained from macro etch photos of forged disk and the model prediction. Figure 5 (a) shows the comparison for Experimental Disk-1 Preform Shape (ED1-P) in Alloy 718 and Figure 5(b) for 
Experimental Disk-1 Finish Shape (ED1-F) in Alloy 718. Figure 6 shows the comparison of the measured grain sizes and the model prediction and for (a) Experimental Disk-1 Preform Shape (ED1-P) in Alloy 718 and (b) Experimental Disk-1 Finish Shape (ED1-F) in Alloy 718. Figure 7 compares of the measured fraction of recrystallization and the model prediction for Experimental Disk-1 Finish Shape (ED1-F)in Alloy 718 and Figure 8 compares the measured fraction of recrystallization and ASTM grain size and the model prediction for Experimental Disk-2 Finish Shape (ED2-F) in Alloy 718. In all of these cases, the model prediction agrees very well with the experimental measurement.

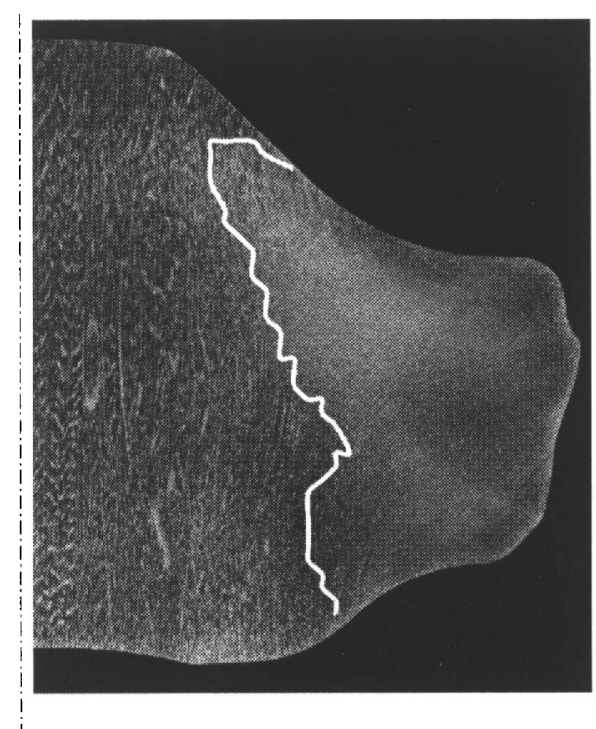

$\mathbb{C}$

(a)

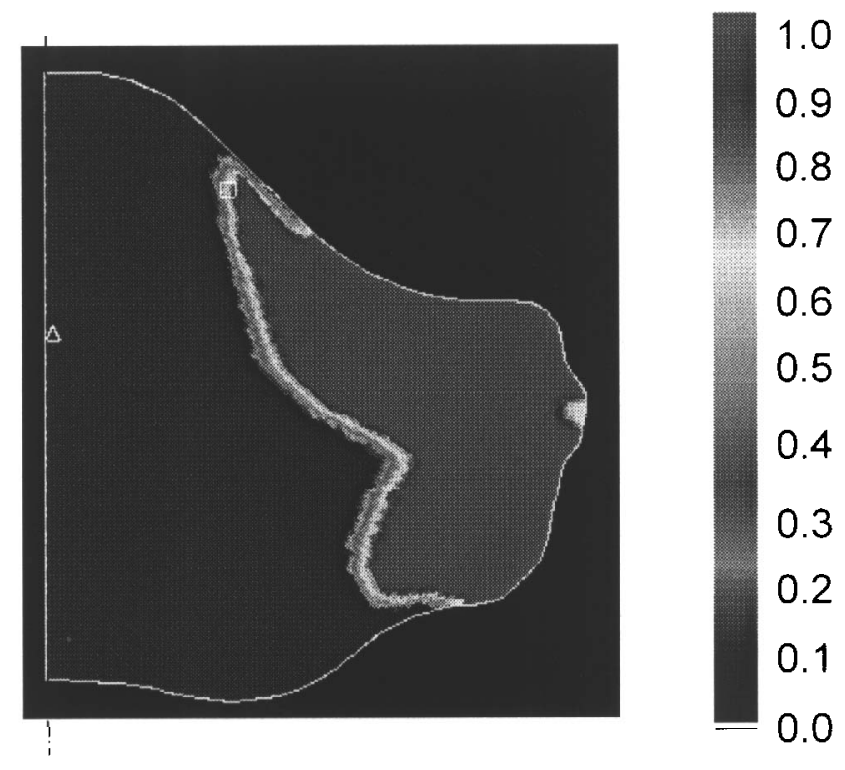

$\mathbb{E}$

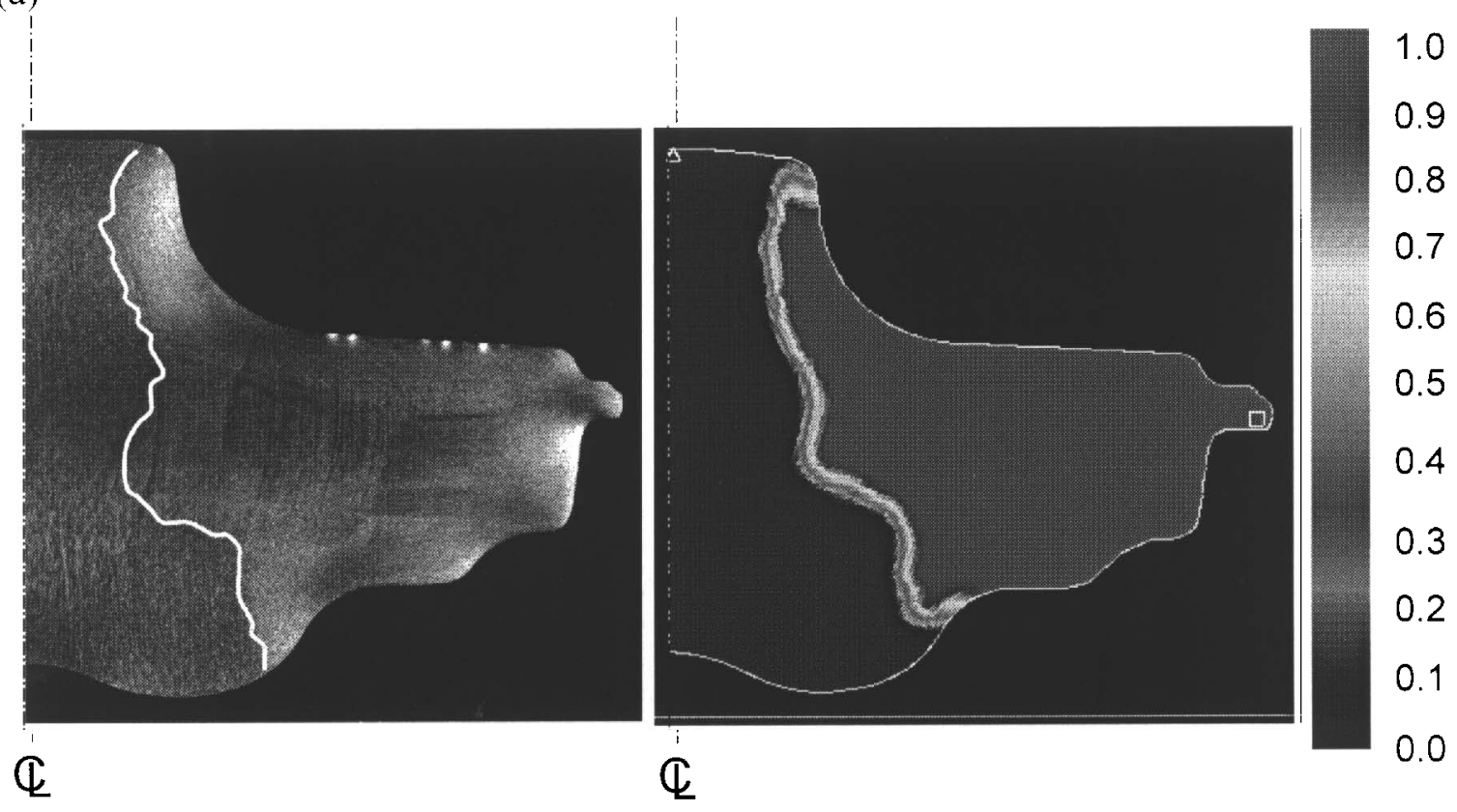

(b)

Figure 5 Comparison of the border between recrystallized and unrecrystallized zone obtained from macro etch photos and model prediction: (a) ED1-P disk in Alloy 718; (b) ED1-F disk in Alloy 718 . 

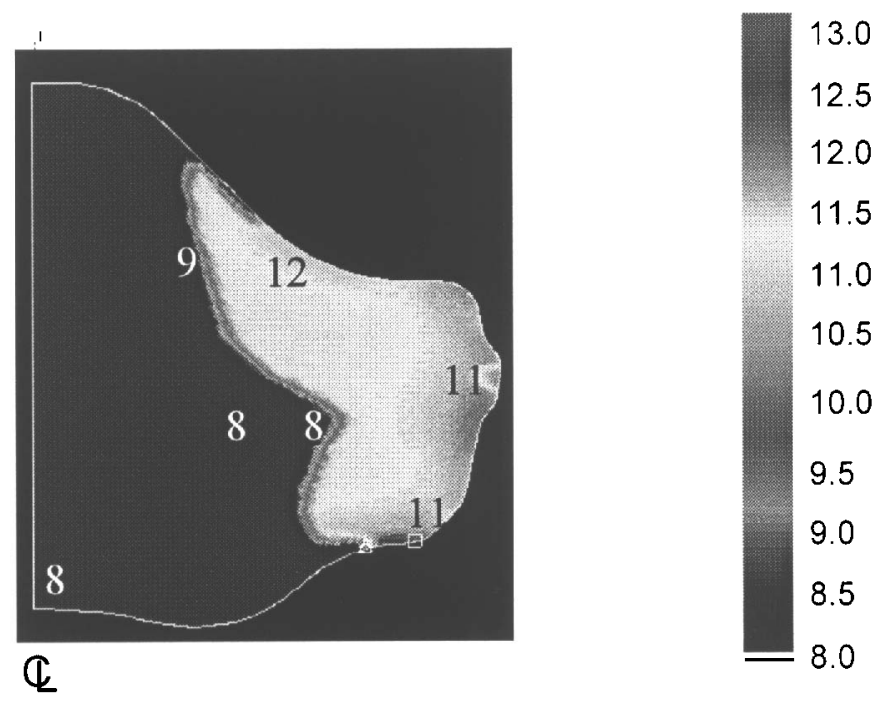

(a)

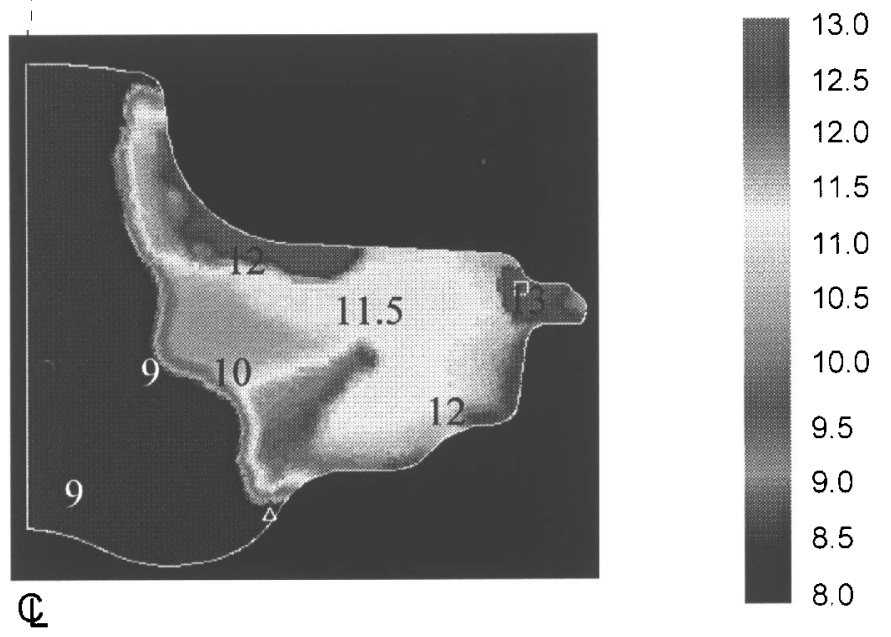

(b)

Figure 6. Comparison of model predicted and measured ASTM grain sizes for (a) ED1-P disk in Alloy 718; (b) ED1-F disk in Alloy 718. 

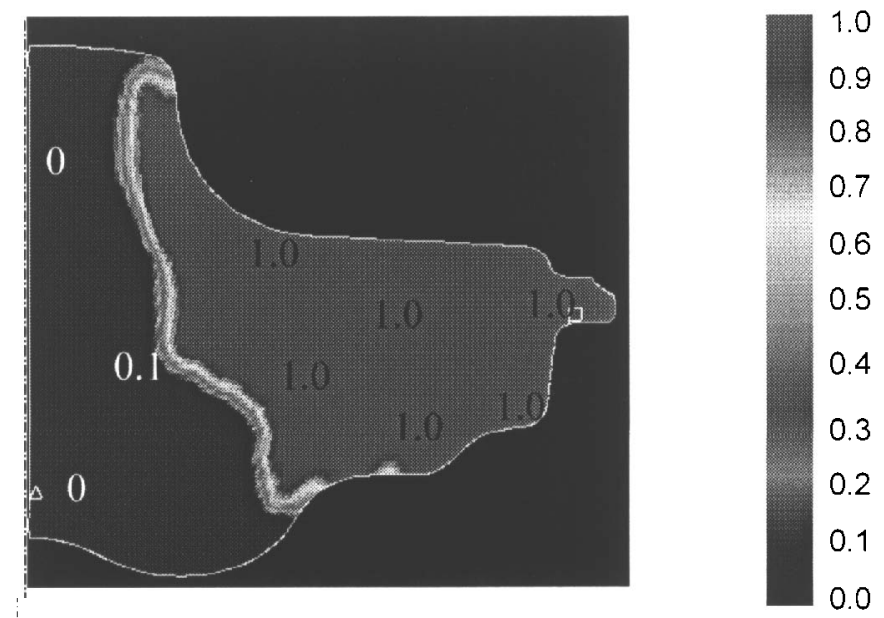

$\mathbb{C}$

Figure 7 Model predicted and measured fraction of RX for ED1-F disk in Alloy 718.

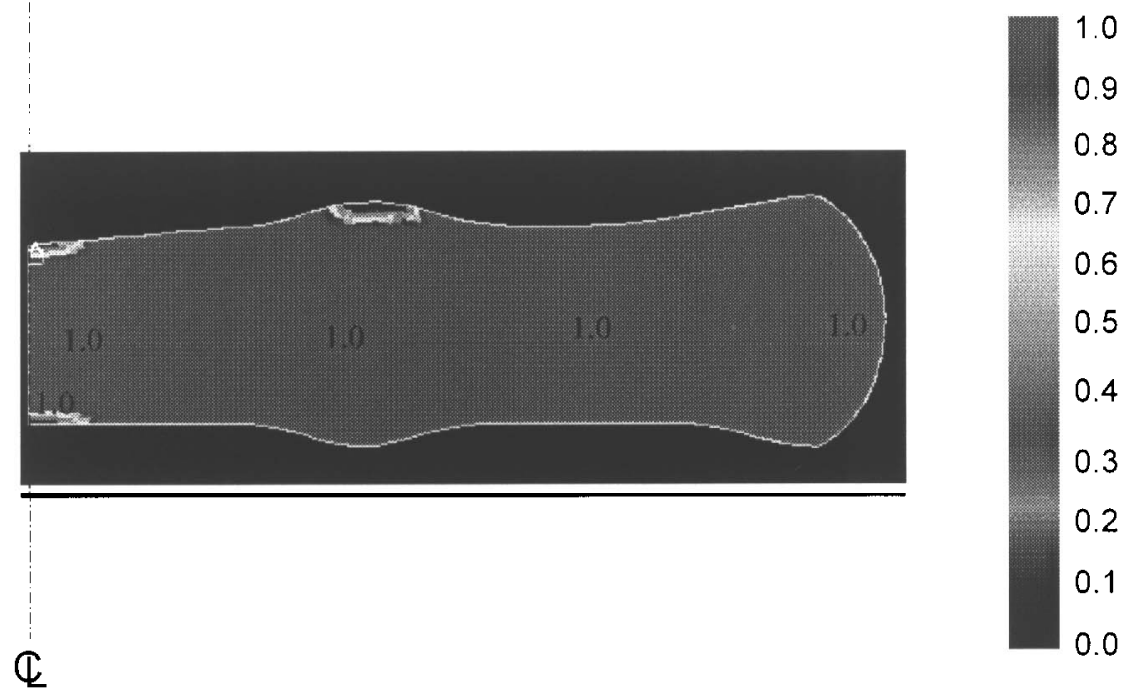

(a)

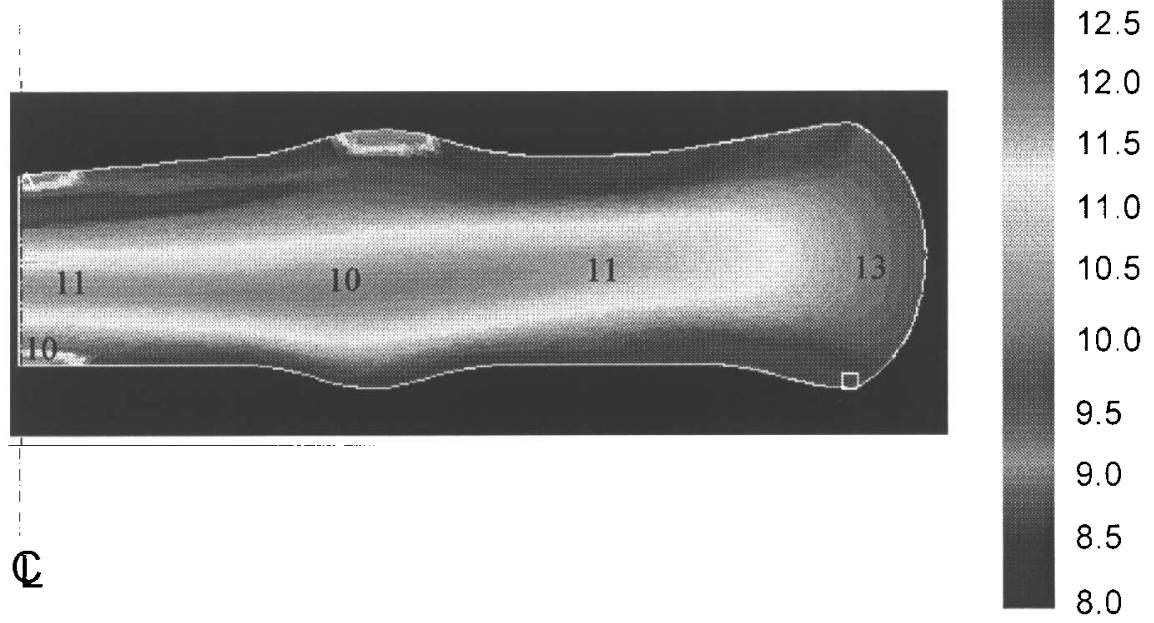

(b)

Figure 8 Comparison of model predicted and measured (a) fraction of RX, and (b) ASTM grain size, for ED2-F disk in Alloy 718. 
The control of the thermomechanical processing is key and critical to the control of subsequent microstructural evolution. The microstructure that results from forging and heat treatment processes directly control the final mechanical properties of specific components. Alloy 718 is utilized in numerous demanding aerospace applications due to its ability to achieve and maintain outstanding mechanical properties. The mechanical properties of hammer forged 718 have been show to be equal or superior to those developed by alternate thermomechanical processing cycles. Table 5 shows the grain size and mechanical properties of hammer forged Alloy 718 disks. Hammer forged Alloy 718 exhibits a good combination of tensile and creep properties.

Table 5 Grain Size and Mechanical Properties of a Hammer Forged Alloy 718 Disk.

\begin{tabular}{|c|c|c|}
\hline Properties & Goal (Minimum) & Hammer Forged Disk \\
\hline ASTM Grain Size & Average 10 ALA 2 & Average 11 ALA 8 \\
\hline 1200F Elongation & $12 \%$ & $19 \%$ \\
\hline 1200F RA & $20 \%$ & $41 \%$ \\
\hline 1200F Yield Strength (KSI) & 140 & 167 \\
\hline $1200 F$ UTS (KSI) & 165 & 187 \\
\hline 1100F Creep & $0.2 \%$ Max 30 hrs Min & $0.19 \% \quad 300 \mathrm{hrs}$ \\
\hline
\end{tabular}

This research also shows that by combination of $\mathrm{CCH}$ processing and modeling tools a better hammer forging process can be developed that allows for greatly reduced die chilling and results in increased component uniformity and reduced input material weight. These are key factors for current and future aerospace components that require increasing component capability with ever decreasing manufacturing cost.

\section{Conclusions}

- A hammer forge energy partitioning model was developed at Ladish.

- The energy partitioning model was validated by means of correlation to forging step-down trials.

- Hammer forged 4340 steel, Ti-6242, Alloy 718, and Waspaloy have been accurately process modeled.

- The grain sizes of hammer forged Alloy 718 disks have been accurately predicted.

- Computer controlled hammer forging processes have been shown to produce high quality Alloy 718 parts that meet and exceed the properties obtained by alternate processes.

- By combination of $\mathrm{CCH}$ processing and modeling tools, a hammer forging process can be developed that allows for greatly reduced die chilling and results in increased component uniformity. 


\section{References}

[1] D. Furrer, "Computer Controls Enhance Hammer Forging," Advanced Materials \& Processes, 1 (1999), 81-83.

[2] G. Shen, and D. Furrer, "Manufacturing of Aerospace Forging," Journal of Materials Processing Technology, 98 (2000), 189-195.

[3] D. Furrer, "Ladish Pushes for Higher Aerospace Forging Performance," Metallurgia, June (1998), 25-27.

[4] T. Furman, and R. Shankar, "Keys to Modeling the Forging Process," Advanced Materials \& Processes, 9 (1998), 45-46.

[5] G. Shen, R. Shivpuri, S.L. Semiatin, and J. Y. Lee, "Investigation of Microstructure and Thermal Mechanical History in the Hammer Forging of an Incoloy 901 Disk," Annals of the CIRP, 42 (1) (1993), 343-346.

[6] G. Shen, "Microstructure Modeling of Forged Components of Ingot Metallurgy Nickel Based Superalloys," Advanced Technologies for Superalloy Affordability, ed. K.-M. Chang, S.K. Srivastava, D.U. Furrer, and K.R. Bain, TMS, (2000), 223-231.

[7] G. Shen, J. Rollins, and D. Furrer, "Microstructure Modeling of Forged Waspaloy Discs," Superalloys 1996, TMS, Warrendale, PA, (1996), 613-620. 